\title{
AKTIVITAS ANTIOKSIDAN EKSTRAK ETANOL DAUN SAWO MANILA (Acrhras zapota L.) MENGGUNAKAN METODE DPPH (1,1-diphenyl-2-picrylhydrazil)
}

\author{
Antioxidant Actyvity Of Sawo Manila Leaves (Acrhras Zapota L.) Ethanol Extract Using DPPH \\ (1,1-Diphenyl-2-Picrylhydrazil)
}

Rugayyah Alyidrus ${ }^{1}$, A. Suparlan Isya Samsu, Nurjannah

Fakultas Farmasi, Universitas Megarezky

${ }^{*}$ rugayyahalyidrus@gmail.com

\begin{abstract}
ABSTRAK
Ekstrak etanol daun sawo manila (Acrhras zapota L.) mengandung senyawa flavonoid yang memiliki aktivitas sebagai antioksidan. Tujuan penelitian ini untuk mengetahui apakah ekstrak etanol daun sawo manila (Acrhras zapota L.) memiliki aktivitas antioksidan dengan metode DPPH (1,1-diphenyl-2-picrylhydrazil). Ekstrak dibuat dengan metode maserasi menggunakan pelarut etanol 70\%. Ekstrak etanol daun sawo manila (Acrhras zapota L.) dibuat larutan induk 1000 ppm setelah itu dilakukan pengenceran 20, 40,60, dan 80 ppm. Kontrol positif (Vitamin C) dengan konsentrasi 2, 4, 6, dan 8 $\mathrm{ppm}$. Dari masing-masing konsentrasi diambil $1 \mathrm{ml}$ lalu di tambahkan $2 \mathrm{ml}$ larutan DPPH (1,1-diphenyl-2-picrylhydrazil), kemudian dihomogenkan dan diinkubasi selama 30 menit. Setelah itu,dilakukan pengukuran spektrofotometer UV-Vis pada panjang gelombang $517 \mathrm{~nm}$. Data hasil dianalisis pengukuran absorbansi menggunakan grafik hubungan konsentrasi dengan persen inhibisi DPPH (1,1-diphenyl-2-picrylhydrazil). Hasil penelitian menunjukkan bahwa ekstrak etanol daun sawo manila (Acrhras zapota L.) terbukti memiliki aktivitas antioksidan yang sangat kuat dengan nilai $I C_{50}$ $8,2786 \mu \mathrm{g} / \mathrm{mL}$.
\end{abstract}

Kata kunci : Sawo Manila, DPPH, Antioksidan, Spektrofotometer.

\section{ABSTRACT}

Extract Ethanol of Manila Sapodilla (Acrhras zapota L.) contain flavonoid compound with antioxidant activity. Aim of this research is to find out ethanol extract of manila sapodilla (Acrhras zapota L.) has antioxidant activity with DPPH method (1,1-diphenyl-2-picrylhydrazil). Extract was made by using maceration method by using ethanol liquid $70 \%$. Ethanol extract of manila sapodilla (Acrhras zapota L.) was made main liquid 1000 ppm after that therewere dilution of 20, 40, 60, and $80 \mathrm{ppm}$. Positive control (Vitamin C) with concentration 2, 4, 6, and $8 \mathrm{ppm}$. Each of concentration was taken $1 \mathrm{ml}$ then added $2 \mathrm{ml}$ of DPPH (1,1-diphenyl-2-picrylhydrazil) liquid, and then it is homogent and incubated during 30 minutes. After that, measurement of spectrophotometer UV-Vis was conducted in wave length of $517 \mathrm{~nm}$. Result of data was analyzed by using absorbansi with grapic of concentration relationship with percentage of DPPH (1,1-diphenyl-2picrylhydrazil) inhibition. Result of research shows that ethanol extract of manila sapodilla (Acrhras zapota L.) was proven has the antioxidant activity very strong with $I C_{50} 8,2786 \mu \mathrm{g} / \mathrm{mL}$.

Keywords : Manila Sapodilla, DPPH, Antioxidant, Spectrophotometer.

\section{PENDAHULUAN}

Pengobatan tradisional umumnya menggunakan ramuan yang berasal dari tumbuhan, baik berupa akar, kulit batang, kayu, daun, bunga atau bijinya. Selain itu, ada pula yang berasal dari organ binatang dan bahan-bahan mineral. Agar supaya pengobatan tersebut dapat dipertanggungjawabkan maka diperlukan penelitianpenelitian ilmiah seperti farmakologi, toksikologi, identifikasi dan isolasi zat kimia aktif yang terdapat di dalam tumbuhan (Mangela et al, 2016).

Salah satu tanaman yang dapat diolah menjadi obat herbal adalah sawo manila (Acrhras zapota L.). Sawo manila (Acrhras zapota L.) merupakan tanaman yang telah banyak dibudidayakan di Indonesia. Bagian tanaman yang belum mendapatkan perhatian pemanfaatannya adalah daun sawo manila (Acrhras zapota L.). Secara empiris daun sawo manila (Acrhras zapota L.) dapat digunakan sebagai obat alternatif pereda demam, pendarahan, luka, antidiare, maupun bisul (Yunika et al, 2017). dengan cara membuat rebusan atau air seduhan daun sawo manila (Acrhras zapota L.) (Mufti et al, 2017). Sawo manila (Acrhras zapota L.) juga diidentifikasi sebagai sumber yang kaya akan antioksidan (Rahman et al, 2016).

Daun sawo manila (Acrhras zapota L.) mengandung zat-zat aktif seperti saponin, tanin, dan flavonoid (Mufti, et al., 2017). Dari hasil skrining fitokimia menunjukkan bahwa ekstrak daun sawo manila (Acrhras zapota L.) positif mengandung alkaloid, flavonoid, tanin, dan saponin. Studi lainnya juga menunjukkan bahwa ekstrak daun sawo manila (Acrhras 
zapota L.) mengandung senyawa fitokimia seperti terpenoid, glicosida, dan flavonoid (Prihardini, 2015).

Senyawa-senyawa polifenol seperti flavonoid yang terdapat pada tanaman mampu menghambat reaksi oksidasi melalui mekanisme penangkapan radikal (radical scavenging) dengan cara menyumbangkan satu elektron pada elektron yang tidak berpasangan dalam radikal bebas sehingga banyaknya radikal bebas menjadi berkurang. Secara in vitro, flavonoid merupakan inhibitor yang kuat terhadap peroksidasi lipid, sebagai penangkap spesies oksigen atau nitrogen yang reaktif, dan juga mampu menghambat aktivitas enzim lipooksigenase dan sikloogsigenase. Kemampuan flavonoid sebagai antioksidan telah banyak diteliti belakangan tahun ini, dimana flavonoid memiliki kemampuan untuk merubah atau mereduksi radikal bebas dan juga sebagai anti radikal bebas (Toripah et al, 2014).

Radikal bebas merupakan suatu molekul yang memiliki elektron tidak berpasangan dalam orbital terluarnya sehingga sangat reaktif. Radikal ini cenderung mengadakan reaksi berantai yang apabila terjadi di dalam tubuh akan dapat menimbulkan kerusakan-kerusakan yang berlanjut dan terus menerus. Tubuh manusia memiliki sistem pertahanan endogen terhadap serangan radikal bebas terutama terjadi melalui peristiwa metabolisme sel normal dan peradangan. Jumlah radikal bebas dapat mengalami peningkatan yang diakibatkan faktor stress, radiasi, asap rokok dan polusi lingkungan menyebabkan sistem pertahanan tubuh yang ada tidak memadai, sehingga tubuh memerlukan tambahan antioksidan (Wahdaningsih et al, 2011).

Antioksidan yang tersedia dalam tubuh tidak sebanding dengan banyaknya radikal bebas yang mungkin masuk ke dalam tubuh. Oleh karena itu, untuk menangkap dan mencegah radikal bebas tersebut agar tidak merusak sel-sel tubuh, maka diperlukan tambahan antioksidan dari luar tubuh (Budiana et al, 2016).

Penggunaan senyawa antioksidan semakin berkembang baik untuk makanan maupun untuk pengobatan seiring dengan bertambahnya pengetahuan tentang aktivitas radikal bebas. Stres oksidatif merupakan keadaan yang tidak seimbang antara jumlah molekul radikal bebas antioksidan di dalam tubuh. Senyawa antioksidan merupakan suatu inhibitor yang digunakan untuk menghambat autooksidasi. Efek antioksidan senyawa fenolik dikarenakan sifat oksidasi yang berperan dalam menetralisasi radikal bebas (Mangela et al,2016).

Antioksidan sintetik memberikan efek toksik dan karsinogenik pada tubuh manusia sehingga dilakukan usaha untuk mencari antioksidan alami yang berasal dari tumbuhan yang dianggap lebih baik dan lebih aman dari antioksidan sintetik, khususnya apabila ditinjau dari segi kesehatan (Rosahdi et al, 2013).

Berdasarkan uraian diatas, perlu dilakukan penelitian tentang tanaman sawo manila (Acrhras zapota L.) sebagai antioksidan karena mengandung senyawa flavonoid yang bersifat antioksidan, khususnya daun sawo manila (Acrhras zapota L.)). dilihat dari beberapa manfaat yang dapat diambil dari penggunaan obat tradisonal lebih mudah mendapatkannya, serta efek samping yang ditimbulkan relatif kecil sehingga aman digunakan (Mangela et al, 2016). Oleh karena itu, penelitian yang mengembangkan sediaan antioksidan yang berasal dari bahan-bahan alami perlu dilakukan (Rosahdi et al, 2013).

\section{METODE}

\section{Desain, tempat dan waktu}

Desain Penelitian ini dilakukan dengan menggunakan metode eksprimental yaitu penelitian yang dilaksanakan di laboratorium dan bertujuan untuk mengetahui apakah ekstrak etanol daun sawo manila (Acrhras zapota L.) memiliki aktivitas antioksidan dengan metode DPPH (1,1-diphenyl-2-picrylhydrazil) bertempat di Laboratorium Fitokimia Megarezky pada bulan Juni-September 2020.

\section{Bahan dan alat}

Alat-alat yang digunakan dalam penelitian ini yaitu batang pengaduk (Pyrex), bejana maserasi (toples kaca), cawan porselin, erlanmeyer (Pyrex), gelas arloji (Pyrex), gelas kimia (Pyrex), gelas ukur (Pyrex), inkubasi, kamera digital, kuvet, labu ukur $10 \mathrm{ml}$ (Pyrex), labu ukur $100 \mathrm{ml}$ (Pyrex), lumpang dan alu, mikropipet (Dragon onemed), pipet ukur (Iwaki pyrex), rak tabung, rotary evaporator (Heidolph), sendok tanduk, spatula (Stainless), sudip, spektrofotometer UV-Vis (Optima SP-300), tabung reaksi (Pyrex), timbangan analitik (Henher). 
Bahan yang digunakan yaitu alumunium foil, aquadest, daun sawo manila (Acrhras zapota L.), DPPH (1,1-diphenyl-2picrylhydrazil), etanol $70 \%$, etanol $96 \%$, kertas perkamen, kertas saring, $\mathrm{NaOH}, \mathrm{pb}$ asetat (timbal asetat) dan vitamin C (Asam askorbat).

\section{Langkah- Langkah Penelitian \\ Pengambilan sampel}

Sampel yang digunakan pada penelitian ini adalah daun dari tanaman sawo manila (Acrhras zapota L.), diambil dengan cara memetik dari batang pohon, pada jam 08.00 karena pada jam tersebut dimana tanaman mengalami proses fotosintesis. Tanaman tersebut diperoleh dari Desa Marumpa, Kec Marusu, Kab Maros Sulawesi selatan.

\section{Pengolahan sampel}

Daun sawo manila (Acrhras zapota L.) dibersihkan dari kotoran yang menempel dengan menggunakan air mengalir sampai benar-benar bersih. Kemudian daun sawo manila (Acrhras zapota L.) dikeringkan dengan cara diangin-anginkan dalam suhu kamar sampai benar-benar kering (Simplisia kering).

Pembuatan ekstrak etanol daun sawo manila (Acrhras zapota L.).

Sampel sawo manila (Acrhras zapota L.) yang telah diserbukkan ditimbang sebanyak 500 gram dimasukkan kedalam wadah maserasi, kemudian direndam dengan pelarut etanol $70 \%$, ekstrak yang dihasilkan kemudian dikumpulkan lalu dipekatkan menggunakan freeze dryer menjadi ekstrak kering.

\section{Uji Aktivitas Antioksidan}

Pembuatan larutan DPPH (1,1-diphenyl-2picrylhydrazil)

Ditimbang DPPH sebanyak $10 \mathrm{mg}$ lalu dilarutkan dengan etanol $96 \%$, kemudian dimasukkan kedalam labu ukur $100 \mathrm{ml}$, dicukupkan volumenya dengan etanol sampai tanda batas, kemudian dimasukkan kedalam botol gelap.

Pembuatan larutan uji ekstrak etanol $70 \%$ daun sawo manila (Acrhras zapota L.)

Ekstrak etanol kering daun sawo manila (Acrhras zapota L.) ditimbang sebanyak $10 \mathrm{mg}$ dilarutkan dengan etanol 96\% kedalam labu ukur $10 \mathrm{ml}$, dicukupkan volumenya dengan etanol $96 \%$ sampai tanda batas, sehingga diperoleh konsentrasi 1000 ppm (larutan induk). Dari larutan induk dipipet sebanyak $0,2 \mathrm{ml}, 0,4 \mathrm{ml}, 0,6 \mathrm{ml}$, dan $0,8 \mathrm{ml}$ lalu dimasukkan kedalam labu ukur $10 \mathrm{ml}$ dicukupkan volumenya sampai tanda batas. Sehingga diperoleh larutan dengan konsentrasi 20 ppm, 40 ppm, 60 ppm, dan $80 \mathrm{ppm}$.

Pembuatan bahan pembanding vitamin $\mathrm{C}$

Ditimbang vitamin C sebanyak 10 $\mathrm{mg}$ lalu dilarutkan dengan $100 \mathrm{ml}$ etanol 96\% kedalam labu ukur $100 \mathrm{ml}$ dicukupkan volumenya dengan etanol $96 \%$ sampai tanda batas, sehingga diperoleh konsentrasi 100 ppm. Masing-masing larutan stok dipipet sebanyak $0,2 \mathrm{ml}, 0,4 \mathrm{ml}, 0,6 \mathrm{ml}$, dan $0,8 \mathrm{ml}$. Lalu dimasukkan kedalam labu ukur $10 \mathrm{ml}$ dicukupkan volumenya dengan etanol hingga tanda batas. Sehingga diperoleh larutan dengan konsentrasi 2 ppm, 4 ppm, 6 ppm, dan 8 ppm.

Uji aktivitas antioksidan menggunakan spektrofotometri UV-Vis.

Pengujian dilakukan dengan memipet $1,0 \mathrm{ml}$ larutan sampel dan larutan baku vitamin $C$ dari berbagai konsentrasi. Kemudian masing-masing ditambahkan 2,0 mI DPPH 1000 ppm. Dari campuran tersebut kemudian dihomogenkan dan diinkubasi selama 30 menit ditempat gelap. Lalu serapannya diukur pada panjang gelombang $517 \mathrm{~nm}$.

Pengukuran Blanko

Pengujian dilakukan dengan memipet $1,0 \mathrm{ml}$ etanol $96 \%$ lalu ditambahkan 2,0 DPPH 1000 ppm. Dari campuran tersebut kemudian dihomogenkan dan diinkubasi selama 30 menit ditempat gelap. Lalu serapannya diukur panjang gelombang $517 \mathrm{~nm}$.

\section{HASIL}

Hasil penelitian menunjukkan bahwa ekstrak etanol sawo manila (Acrhras zapota L.) memiliki aktivitas antioksidan yang sangat kuat dengan nilai $\mathrm{IC}_{50}$ yaitu $8,2786 \mu \mathrm{g} / \mathrm{mL}$. dan vitamin C sebagai pembanding juga memiliki aktivitas antioksidan yang sangat kuat dengan nilai $\mathrm{IC}_{50}$ yaitu $0,8835 \mu \mathrm{g} / \mathrm{mL}$.

\section{PEMBAHASAN}

Antioksidan adalah senyawa yang mampu menangkal atau merendam dampak 
negatif oksidan dalam tubuh. Antioksidan bekerja dengan cara mendonorkan satu elektronnya kepada senyawa yang bersifat oksidan sehingga aktivitas senyawa oksidan tersebut dapat dihambat (Winarsi, 2007). Khasiat antioksidan untuk mencegah berbagai penyakit akibat pengaruh oksidatif akan lebih efektif jika kita mengkonsumsi sayur-sayuran dan buah-buahan yang kaya akan antioksidan daripada menggunakan antioksidan tunggal. Efek antioksidan dari sayur-sayuran dan buah-buahan, lebih efektif daripada suplemen antioksidan yang isolasi. Hal ini mungkin dikarenakan oleh adanya komponen lain dan interaksinya dalam sayur-sayuran dan buah-buahan yang berperan secara positif (Silalahi, 2006).

Penelitian ini menggunakan sampel Daun Sawo Manila (Acrhras zapota L.) yang diambil dari desa marumpa kecamatan marusu kabupaten maros sulawesi selatan. Penelitian ini bertujuan untuk mengetahui apakah ekstrak etanol daun sawo manila (Acrhras zapota L.) memiliki aktivitas antioksidan dengan metode DPPH $(1,1$ diphenyl-2-picrylhydrazil).

Daun sawo manila (Acrhras zapota L.) dibersihkan dari kotoran yang menempel dengan menggunakan air mengalir sampai benar-benar bersih. Kemudian daun sawo manila (Acrhras zapota L.) dikeringkan dengan cara diangin-anginkan dalam suhu kamar sampai benar-benar kering (Simplisia kering).

Daun sawo (Acrhras zapota L.) yang berfungsi sebagai sumber energi, menyehatkan pencernaan, mengatasi sembelit, menyembuhkan diare, menangkal radikal bebas, meningkatkan imunitas tubuh, mencegah kanker, melancarkan metabolisme tubuh, anti radang dan anti bakteri (Murtie, 2014).

Metode ekstraksi dalam penelitian ini adalah maserasi, karena daun memiliki tekstur yang lunak, dan metode ini baik digunakan untuk sampel dengan tekstur yang lunak dan tidak tahan terhadap pemanasan secara langsung. Maserasi yang dilakukan dengan cara merendam serbuk simplisia dalam cairan penyari dan disimpan terlindung dari cahaya matahari langsung (mencegah reaksi yang dikatalisasi cahaya atau perubahan warna). Pelarut yang digunakan dalam penelitian ini yaitu etanol, karena pelarut etanol mempunyai poralitas yang tinggi sehingga dapat menghasilkan ekstraksi lebih banyak dibandingkan pelarut lainnya (Prihardini et al 2015). Hal ini dikarenakan etanol mampu melarutkan sebagian besar zat aktif, memperbaiki stabilitas bahan obat, menghambat kerja enzim yang dapat merusak zat aktif, sulit ditumbuhi kapang dan kuman, serta membutuhkan panas yang lebih sedikit dalam proses pemekatan sehingga tidak merusak zat aktif yang tidak tahan panas (Mufti et al, 2017). Ekstraksi daun sawo manila (Acrhras zapota L.) dilakukan secara maserasi dengan menggunakan cairan penyari etanol $70 \%$. karena berdasarkan prinsip ekstraksi bahwa penarikan suatu senyawa didasarkan pada kepolarannya, dan disimpulkan bahwa etanol $70 \%$ dapat menarik senyawasenyawa baik polar atau non polar seperti alkaloid, flavonoid, tanin, saponin dan steroid.

Hasil rendemen ekstrak etanol daun sawo manila (Acrhras zapota L.) yang diperoleh dari proses ekstraksi sebanyak $40,2 \%$. Setelah itu, dilakukan pengujian fitokimia untuk golongan senyawa flavonoid. Berdasarkan hasil penelitian, maka dapat disimpulkan bahwa senyawa flavonoid memiliki potensi sebagai antioksidan, karena flavonoid merupakan senyawa polifenol mempunyai kemampuan untuk menyumbangkan atom hidrogen kepada senyawa radikal bebas, maka aktivitas antioksidan senyawa polifenol dapat dihasilkan pada reaksi netralisasi radikal bebas atau pada penghentian reaksi berantai yang terjadi. Dari pengujian fitokimia dilanjutkan pengujian aktivitas antiradikal bebas dengan menggunakan DPPH (1,1 diphenyl-2-picrylhydrazil).

Pengujian aktivitas antioksidan ekstrak dilakukan dengan menggunakan metode DPPH (1,1 diphenyl-2picrylhydrazil). Berdasarkan pada penelitian terdahulu metode ini paling umum digunakan untuk menguji aktivitas antioksidan sampel secara in vitro dan juga merupakan metode yang sederhana, cepat, dan tidak membutuhkan banyak reagen seperti halnya metode lain. Selain itu metode ini juga tebukti akurat, reliable, dan praktis. Pengukuran dilakukan dengan menggunakan spektrofotometer UV-Vis. Penentuan panjang gelombang DPPH $(1,1$ diphenyl-2-picrylhydrazil) dilakukan pada $517 \mathrm{~nm}$ dan selanjutnya dengan metode perendaman radikal DPPH (1,1 diphenyl-2picrylhydrazil) dilakukan pada panjang gelombang tersebut (Sayuti, 2015). 
Pada penelitian ini ekstrak etanol daun sawo manila (Acrhras zapota L.) dibuat larutan induk 1000 ppm, dari larutan induk tersebut tiap ekstrak dilakukan pengenceran dengan konsentrasi yang berbeda-beda yaitu 20 ppm, 40 ppm, 60 ppm, dan 80 ppm sebagai larutan uji. Sedangkan pada vitamin C dibuat larutan pembanding 100 ppm, dari larutan pembanding tersebut dilakukan juga pengenceran dengan konsentrasi yang berbeda yaitu 2, 4, 6 dan 8 ppm. Dari masing-masing larutan uji dan larutan pembanding dengan konsentrasi tersebut, diambil $1 \mathrm{ml}$ lalu ditambahkan $2 \mathrm{ml}$ larutan DPPH (1,1 diphenyl-2-picrylhydrazil) Campuran tersebut dihomogenkan, lalu diinkubasi selama 30 menit di ruang gelap. Hal tersebut dilakukan karena untuk mengoptimumkan aktivitas DPPH $(1,1$ diphenyl-2-picrylhydrazil) agar terjadi reaksi antara DPPH dengan sampel yang diuji. Setelah diinkubasi, kemudian dilakukan pengukuran spektrofotometer pada panjang gelombang $517 \mathrm{~nm}$. Karena pengukuran spektrofotometer pada panjang gelombang $517 \mathrm{~nm}$ merupakan panjang gelombang maksimum DPPH $(1,1$ diphenyl-2picrylhydrazil), dengan konsentrasi DPPH (1,1 diphenyl-2-picrylhydrazil) $50 \mathrm{Mm}$. Adanya aktivitas antioksidan dari sampel mengakibatkan terjadinya perubahan warna pada larutan DPPH (1,1 diphenyl-2picrylhydrazil) dalam etanol yang semula berwarna violet pekat menjadi kuning pucat (Wahdaningsih et al, 2011). Semakin besar konsentrasi sampel maka semakin banyak elektron yang didonorkan untuk merendam radikal bebas, dalam hal ini DPPH $(1,1$ diphenyl-2-picrylhydrazil), sehingga absorbansinya yang diberikan pun semakin menurun (Toripah et al. 2014).

Dari hasil pengukuran absorbansi yang diperoleh maka dapat dilihat pada Tabel.2, menunjukkan bahwa konsentrasi $80 \mathrm{ppm}$ memiliki aktivitas paling tinggi yaitu $62,34 \%$, pada konsentrasi $60 \mathrm{ppm}$ yaitu $39,57 \%$, pada konsentasi $40 \mathrm{ppm}$ yaitu 33,40 ppm, sedangkan pada konsentrasi 20 ppm yaitu $20,43 \%$. Parameter yang digunakan untuk menunjukkan aktivitas antioksidan adalah (Inhibitor Concentration IC 50 ) (Toripah et al, 2014).

$\mathrm{IC}_{50}$ merupakan konsentrasi dari antioksidan yang dapat merendam atau menghambat $50 \%$ radikal bebas. Besarnya aktivitas antioksidan ditandai dengan besarnya nilai $\mathrm{IC}_{50}$, yaitu konsentrasi larutan sampel yang dibutuhkan untuk merendam
$50 \%$ radikal bebas DPPH (1,1 diphenyl-2picrylhydrazil). Semakin kecil nilai $\mathrm{IC}_{50}$ berarti semakin tinggi aktivitas antioksidan dan suatu senyawa dikatakan sebagai antioksidan sangat kuat jika nilai $\mathrm{IC}_{50}$ kurang dari $50 \mathrm{ppm}$, kuat untuk $\mathrm{IC}_{50}$ bernilai 50-100 ppm, sedang jika bernilai $100-150$ ppm, dan lemah jika nilai $I_{50}$ bernilai $150-200$ ppm, sangat lemah jika nilai I $C_{50}$ bernilai 200-1000 ppm (Mangela et al, 2016).

Berdasarkan hasil penelitian menunjukkan bahwa ekstrak etanol sawo manila (Acrhras zapota L.) memiliki aktivitas antioksidan yang sangat kuat dengan nilai $\mathrm{IC}_{50}$ yaitu $8,2786 \mu \mathrm{g} / \mathrm{mL}$. dan vitamin $\mathrm{C}$ sebagai pembanding juga memiliki aktivitas antioksidan yang sangat kuat dengan nilai $\mathrm{IC}_{50}$ yaitu $0,8835 \mu \mathrm{g} / \mathrm{mL}$.

\section{KESIMPULAN}

Kesimpulan berisi jawaban dari Berdasarkan penelitian yang telah dilakukan dapat disimpulkan bahwa ekstrak etanol daun sawo manila (Acrhras zapota L) terbukti memiliki aktivitas antioksidan yang sangat kuat dengan nilai $I_{50}$ yaitu 8,2786 $\mu \mathrm{g} / \mathrm{mL}$.

\section{SARAN}

Diharapkan penelitian ini dilanjutkan dengan membuat sedian formulasi.

\section{UCAPAN TERIMA KASIH}

Penulis ingin mengucapkan banyak terima kasih kepada Deputi Bidang Penguatan Riset dan Pengembangan Kementrian Riset dan Teknologi / Badan Riset Inovasi Nasional (RISTEK-BRIN) Indonesia, Rektor Universitas Megarezky, Ketua LPPM Universitas Megarezky dan semua pihak yang telah membantu berjalannya penelitian ini.

\section{DAFTAR PUSTAKA}

Budiana W, Burhanudin, Asep R. Penetapan Kadar Fenolat Total, Flavanoid Total, Serta Aktivitas Antioksidan Dengan Metode DPPH Dan CUPRAC Pada Ekstrak Daun Sendok (Plantago major L.). Bandung. 2016; 3 (2) : 83.

Mangela $\mathrm{O}$, Musafira, Ridhay A. Kajian Aktivitas Ekstrak Daun Tembelekan (Lantana camara L) Berdasarkan Tingkat Kepolaran Pelarut. FMIPA Universitas Tadulako. Palu. 2016; 2 (3) : 17-22. 
Mufti N, Elizabeth B, Dessy A. Uji Daya Hambat Ekstrak Daun Sawo Terhadap Bakteri Escherichia coli secara In Vitro. Padang. 2017; 6 (2) : 290.

Prihardini, Wiyono A.S. Pengembangan Dan Uji Antibakteri Ekstrak Daun Sawo Manila (Manilkara zapota) Sebagai Lotio Terhadap Staphyllococcus aures. Kediri. 2015; 2 (1) : 90.

Rahman S, Aulia W. Uji Efek Hipoglikemik Ekstrak Etanol Buah Sawo Manila (Manilkara zapota) Pada Mencit Jantan Yang Diinduksi Aloksan. Makassar. 2016; 8 (1) : 77.

Rosahdi T.D, Mimin K, Fitri R.W. Uji Aktivitas Daya Antioksidan Buah Rambutan Rapiah Dengan Metode DPPH. Politeknik Kesehatan. Bandung. 2013.

Sayuti K, Rina Y. Antioksidan Alami Dan Sintetik. Penerbit Andalan University Press: Padang; 2015. p. 7, 10, 47, 51, 75-77.
Silalahi J. Makanan Fungsionl. Kanisius: Yogyakarta; 2006. p. 48-49.

Toripah S, Jemmy A, Frenly W. Aktivitas Antioksidan Dan Kandungan Total Fenolik Ekstrak Daun Kelor (Moringa oleifera LAM.). Manado. 2014; 3 (4) : 38-39, 41.

Wahdaningsih S, Erna P, Subagus W. Aktivitas Penangkap Radikal Bebas Dari Batang Pakis (Alsophila glauca J. sm). Pontianak. 2011; 16 (3) : 157.

Winarsi H. Antioksidan Alami Dan Radikal Bebas. Kanisius: Yogyakarta; 2007. p. 78-82.

Yunika N, Irdawati, Mades F. Konsentrasi Hambat Minimum Ekstrak Daun Sawo (Achras zapota L.) Terhadap Pertumbuhan Staphylococcus aureus Secara In Vitro. Padang; $2017: 53$. 
Tabel 1. Hasil Pengukuran Aktivitas Antioksidan Ekstrak Etanol Daun Sawo Manila (Acrhras zapota L.) pada Spektrofotometer UV-Vis

\begin{tabular}{|c|c|c|c|c|c|}
\hline Sampel & $\begin{array}{c}\text { Konsentrasi } \\
(\text { ppm) }\end{array}$ & Absorbansi & \% Inhibisi & $\begin{array}{c}\text { Persamaan regresi } \\
\text { linear }\end{array}$ & $\mathrm{IC}_{50}$ \\
\hline \multirow{4}{*}{$\begin{array}{l}\text { Ekstrak Etanol } \\
\text { Daun Sawo } \\
\text { Manila (Acrhras } \\
\text { zapota L.) }\end{array}$} & 20 & 0,339 & $20,43 \%$ & \multirow{4}{*}{$\begin{array}{c}y=0.6595 x+5.96 \\
R^{2}=0.9442\end{array}$} & \multirow{4}{*}{$\begin{array}{l}8,2786 \\
\mu \mathrm{g} / \mathrm{mL}\end{array}$} \\
\hline & 40 & 0,301 & $33,40 \%$ & & \\
\hline & 60 & 0,306 & $39,57 \%$ & & \\
\hline & 80 & 0,125 & $62,34 \%$ & & \\
\hline
\end{tabular}

Dari uraian diatas dapat disimpulkan bahwa Hasil Pengukuran Aktivitas Antioksidan Ekstrak Etanol Daun Sawo Manila (Acrhras zapota L.) pada Spektrofotometer UV-Vis yaitu $8,2786 \mu \mathrm{g} / \mathrm{mL}$.

Tabel 2. Hasil Pengukuran Aktivitas Antioksidan Pembanding Vitamin C pada Spektrofotometer $\mathrm{UV}-\mathrm{V}$ is

\begin{tabular}{|c|c|c|c|c|c|}
\hline Sampel & $\begin{array}{c}\text { Konsentrasi } \\
\text { (ppm) }\end{array}$ & Absorbansi & $\%$ Inhibisi & $\begin{array}{c}\text { Persamaan regresi } \\
\text { linear }\end{array}$ & $\mathrm{IC}_{50}$ \\
\hline \multirow{4}{*}{ Vitamin $\mathrm{C}$} & 2 & 0,181 & $61,48 \%$ & \multirow{4}{*}{$\begin{array}{c}y=4.799 x+51.16 \\
R^{2}=0.9958\end{array}$} & \multirow{4}{*}{$\begin{array}{l}0,8835 \\
\mu \mathrm{g} / \mathrm{mL}\end{array}$} \\
\hline & 4 & 0,149 & $69,57 \%$ & & \\
\hline & 6 & 0,090 & $79,36 \%$ & & \\
\hline & 8 & 0,048 & $90,21 \%$ & & \\
\hline
\end{tabular}

Dari uraian diatas dapat disimpulkan bahwa Hasil Pengukuran Aktivitas Antioksidan Pembanding Vitamin C pada Spektrofotometer UV-Vis yaitu $0,8835 \mu \mathrm{g} / \mathrm{mL}$. 